UDC 633.34-154.71

Original research paper

doi:10.5937/AASer1845015M

Acta Agriculturae Serbica, Vol. XXIII, 45 (2018); 15-26

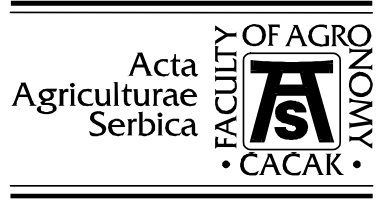

\title{
Effect of priming on soybean seed germination parameters
}

\author{
Zlatica Miladinov $^{1 *}$, Svetlana Balešević-Tubić ${ }^{1}$, Vojin Đukić ${ }^{1}$, \\ Aleksandar Ilić ${ }^{1}$, Lazar Čobanović ${ }^{1}$, Gordana Dozet ${ }^{2}$, Larisa \\ Merkulov-Popadić ${ }^{1}$
}

${ }^{1}$ Institute of Field and Vegetable Crops

Maksima Gorkog 30, 21000 Novi Sad, Serbia

${ }^{2}$ Megatrend University, Faculty of Biofarming

Maršala Tita 39, 24300 Bačka Topola, Serbia

Corresponding author: zlatica.miladinov@ifvens.ns.ac.rs

\begin{abstract}
The objective of this study was to examine the effect of primers on seed quality parameters using different starting values of germination. For this purpose, ten soybean lines selected at the Institute of Field and Vegetable Crops, Novi Sad were evaluated. The starting values of germination ranged between $48 \%$ and $89 \%$. Seeds were surface sterilized with 3\% sodium hypochlorite and immersed in different primers: $1 \%$ potassium nitrate, $1 \%$ potassium chloride and $1 \%$ hydrogen peroxide. Untreated seeds were used as the control. The obtained results revealed that the effects of priming depended on soybean line and treatment, whereas the efficiency of this pre-sowing treatment was not affected by the starting value of seed germination. Some lines responded favorably to immersion, while in others priming had an inhibitory effect, causing a significant decrease in germination. There was an increase in germination up to $12 \%$ or a decrease up to $11 \%$, depending on line and treatment. Lines that were positively affected by this method also exhibited increased values for other germination parameters: mean germination time (MGT) and time to $50 \%$ germination (T50). Lower values of MGT and T50 were observed in lines which showed a negative response to priming and a decrease in germination, but also a more rapid radicle protrusion, as compared to the control.
\end{abstract}


In conclusion, there is no universal applicability of one single primer as it might cause a negative response in some lines and thus reduce seed quality.

Keywords: germination, germination parameters, priming, soybean seed.

\section{Introduction}

Seed priming is a pre-sowing treatment which was used in Ancient Greece in the $4^{\text {th }}$ century $\mathrm{BC}$, when Theophrastus soaked seeds of cucumber in milk or water so as to cause early germination and obtain better seed vigor (Evenari, 1984). Today, seed priming is a cheap and simple pre-sowing treatment, primarily applied in developing countries (Harris et al., 2001) or by agricultural producers who are unable to use expensive and complex methods (Ozdemir, 2012). Priming improves seed viability, synchronizes and accelerates germination and sprouting, increases stress resistance and antioxidant activity, and improves plant productivity and growth (McDonald, 2000).

Priming occurs in three stages. Stage I includes mitochondrial DNA repair and protein synthesis by using the existing RNA, in which seeds absorb a large amount of water (Hussian et al., 2014). Mitochondria and proteins are synthesized during stage II, when supplies, such as proteins, fats and lipids, turn into compounds necessary for germination, and seeds absorb small amounts of water (Bray, 1995).

Stage III involves completion of the germination process and seedling growth, accompanied by a sudden increase in water absorption (Hussian et al., 2014).

As found by Harris (2006) in a study covering a large number of crop producers, priming increased yields of major crops. The increase varied depending on crop and country i.e. agroenvironmental conditions. Yield of mountain rice increased by $10-113 \%$, chickpea by $40 \%$, wheat by $5-35 \%$, and corn by $29 \%$ (Harris, 2006).

The success of seed priming depends on a number of factors, including plant species, water potential of primer, duration, temperature, seed vigor, dehydration, and storage conditions for primed seeds (Parera and Cantliffe, 1994).

The aim of the research was to examine the effect of priming on seed quality parameters with different starting values of germination.

\section{Material and Methods}

Experiments were conducted at the laboratory of the Institute of Field and Vegetable Crops, Novi Sad in 2016. A factorial experiment using seeds of ten soybean lines: L1 (NS-L-220412), L2 (NS-L-400094), L3 (NS-L-220444), L4 (NS-L-210390), L5 (NS-L-410059), L6 (NS-L-201456), L7 (NS-L-200453), L8 (NS-L-401097), L9 (NS-L-420074) and L10 (NS-L-210457) was laid out in a 
completely randomized design with three replications. Seed germination of the lines ranged from $48 \%$ to $89 \%$. Seeds were surface sterilized with $3 \%$ solution of sodium hypochlorite, and thereafter soaked in different primers: $\mathrm{KNO}_{3}(1 \%)$, $\mathrm{KCl}(1 \%)$, and $\mathrm{H}_{2} \mathrm{O}_{2}(1 \%)$. The duration of priming was $6 \mathrm{~h}$ (Miladinov et al. 2015). Seeds were removed at the same time, the surplus of water was carefully removed using a paper toweand seeds were dried to $12-14 \%$ moisture. One hundred seeds were placed evenly on sterilized filter paper in $90 \mathrm{~mm}$ diameter Petri dishes, and treated with a $10 \mathrm{ml}$ water solution. Petri dishes were closed to prevent moisture loss and avoid contamination, placed in a germination chamber and kept at $25{ }^{\circ} \mathrm{C}$ for 8 days. Seed germination was monitored daily, and radicle protrusion of more than $2 \mathrm{~mm}$ was scored as germination. The following parameters were calculated after 8 days:

- Total germination (TG) was measured on the seventh day using the formula

TG $(\%)=($ total number of germinated seeds/ total seed $) \times 100$ (ISTA 2009).

- Mean germination time (MGT) was calculated by the formula of Ellis and Roberts (1981).

MGT $=\Sigma$ (ni/di). With ni: number of germinated seeds and di: day of counting.

- Time to 50\% germination (T50) was determined using the formula of Coolbear et al. (1984) modified by Farooq et al. (2005):

$$
\mathrm{T} 50=\mathrm{ti}+(\mathrm{N} / 2-\mathrm{ni})(\mathrm{tj}-\mathrm{ti}) /(\mathrm{nj}-\mathrm{ni})
$$

where $\mathrm{N}$ is the final number of germinating seeds, $\mathrm{nj}$ and ni are the cumulative number of seeds germinated at times $t \mathrm{j}$ and $\mathrm{t} i$, respectively, when $\mathrm{ni}<\mathrm{N} / 2<$ ni.

All data were subjected to an analysis of variance using STATISTICA software, and differences between means were compared by Duncan's test $(\mathrm{P}<0.05)$

\section{Results and Discussion}

Apart from yield and chemical composition of seed, seed quality is also important from the viewpoint of seed production. For selected soybean lines, germination ranged from $47 \%$ to $89 \%$, as a result of low amounts of rainfall during the critical periods of soybean development. The decrease in seed quality is the main problem in plant production (Dourado and Roberts, 1984). Production 
technology uses various procedures for seed quality improvement. The applied treatments aim to improve seed germination and other seed qualities. They can reduce the effects of seed aging, as well as the negative effects of various stress factors. The mechanism of these procedures is appropriate for certain species and specific for each species (Lekić, 2003). Seed priming is a common method of seed quality improvement.

As shown by the results, the efficiency of this method depends on lines and treatments, with some lines exhibiting a positive response to the pre-sowing treatment and improved values of all the examined quality parameters. Priming was a suitable method for seed quality improvement in these lines (Figure 1).

Figure 1. The effect of priming on soybean seed germination (\%)

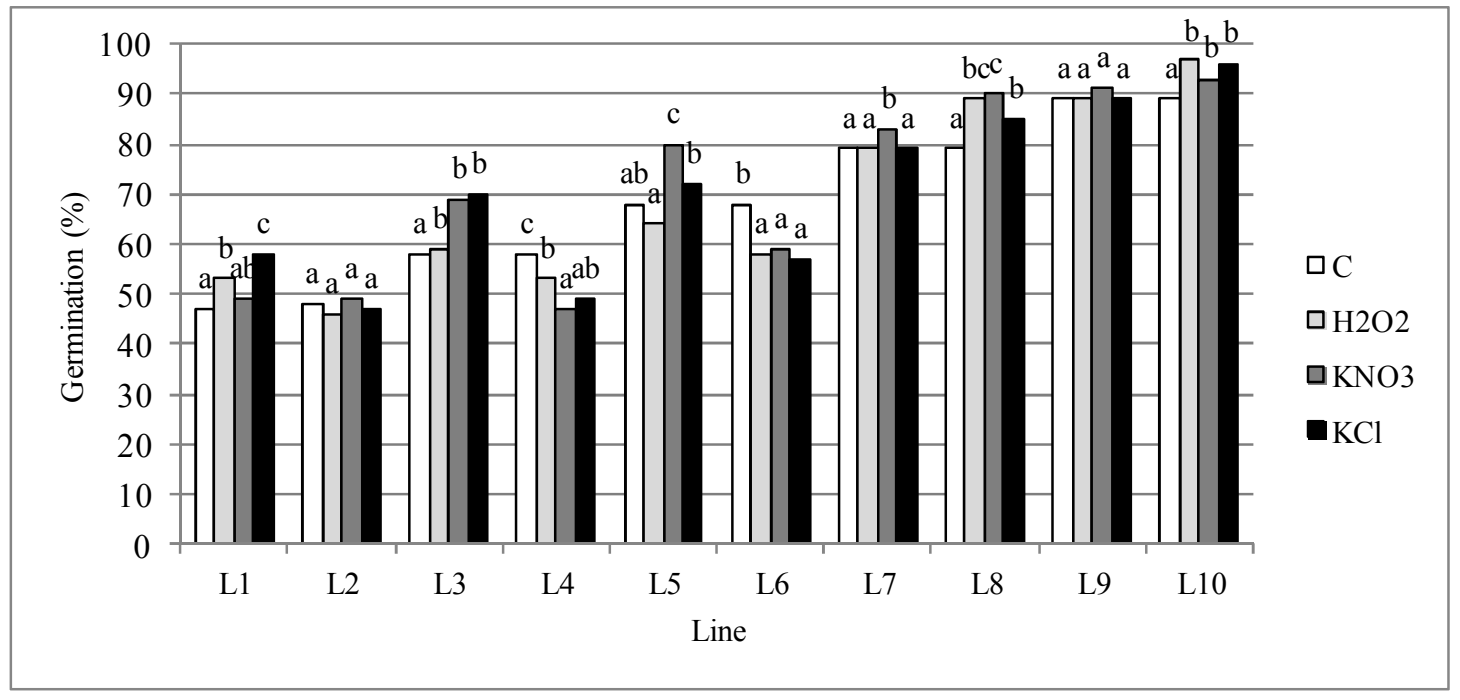

The average increase in germination ranged from $1-9 \%$, and higher values for MGT and T50 were observed compared to the control. Large differences in primer efficiency were determined in some lines. For example, hydrogen peroxide increased germination in line L3 by $1 \%$, whereas a $12 \%$ increase was observed after priming with potassium chloride. Lines L8 and L10 had a positive response to all solutions, which increased their germination by $6-11 \%$ and 4 $7 \%$, respectively. The use of primers can also have an adverse damaging effect on seed quality. . Two lines exhibited a strong negative response to this presowing treatment. The observed decrease in germination was $5-11 \%$ and $9-11 \%$ in lines L4 and L6, respectively. All primers had a positive effect on MGT and T50, regardless of the effect on seed germination. These parameters were lower in lines with a negative response to seed priming, but they exhibited a higher rate of radicle emergence compared to the control. Lines L9 and L10 had the highest 
values of MGT and T50. MGT values were 2.43 and 2.33, and T50 values 1.57 and 1.60, respectively (Figures 2 and 3 ).

Figure 2. The effect of priming on MGT of soybean seeds (day)

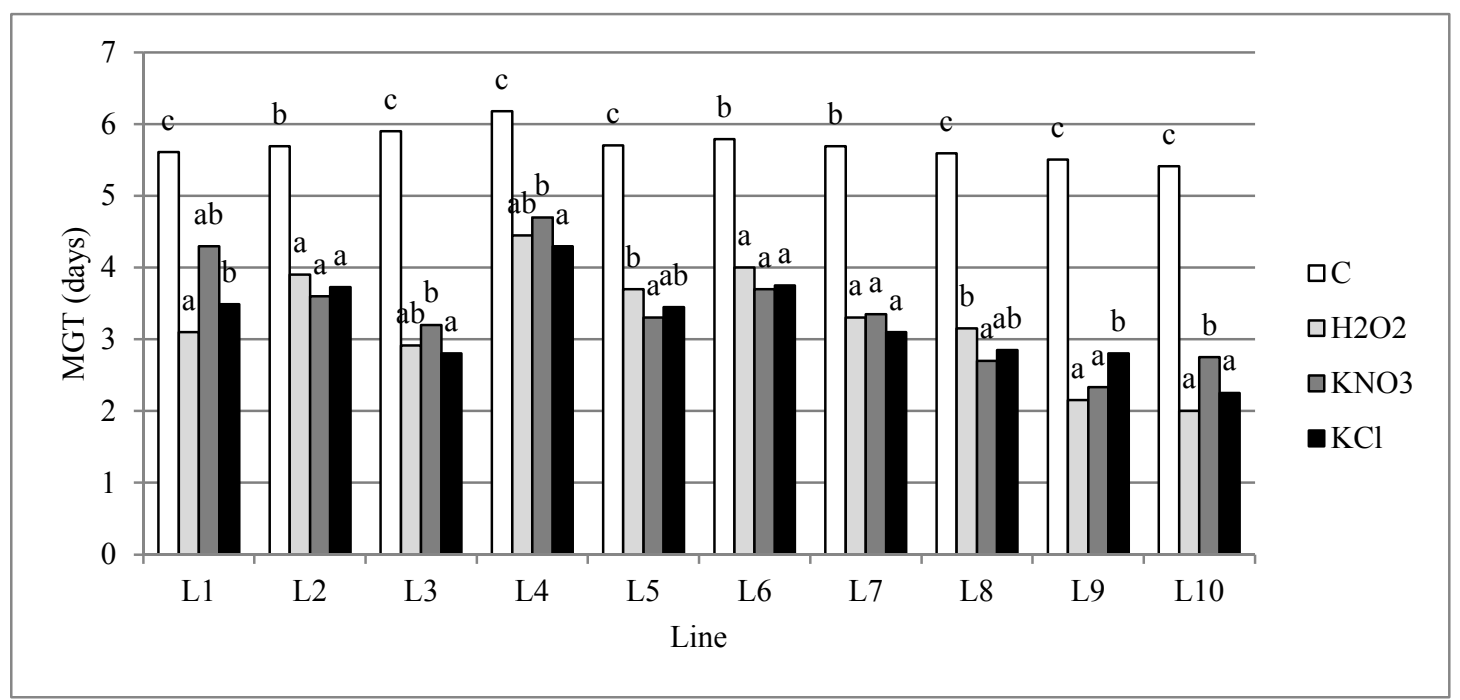

Using wheat as an example, Dezfuli (2008) found that the effect of primers on germination greatly depends on genotype. Miladinov et al. (2014) confirmed different responses to priming in seeds of the same genotype but from different seed lots. Seed quality increase depends on the degree of damage, while an increase in germination energy can be obtained by soaking seeds in specific solutions (Wattanakulpakin et al., 2012). Some solutions can trigger biological activity and improve germination capacity (Schopfer et al., 2001). Priming lowvigor soybean seed improves its germination (Wartidningsih et al., 1994). Priming accelerates germination and promotes initial growth and development (Ahmad et al., 2013). Initial seed quality had no influence on priming effects. Germination in L1 was increased by $5 \%$ at the lowest starting values of this parameter $(47 \%$ i.e. $48 \%)$, while a reduction in seed quality occurred in other lines. Reaction between lines was observed in L3 and L4. Germination increased by $8 \%$ in line L3, while it decreased by $8 \%$ in L4. Starting germination values were not significant for MGT and T50. For example, MGT was 2.97 and 4.48, and T50 2.07 and 2.72 in lines L3 and L4, respectively. Priming with potassium nitrate was the most efficient, with a positive effect on ten lines. The increase ranged between 1 and $12 \%$. No significant change occurred at the lowest starting values. 
Figure 3. The effect of priming on T50 of soybean seeds (day)

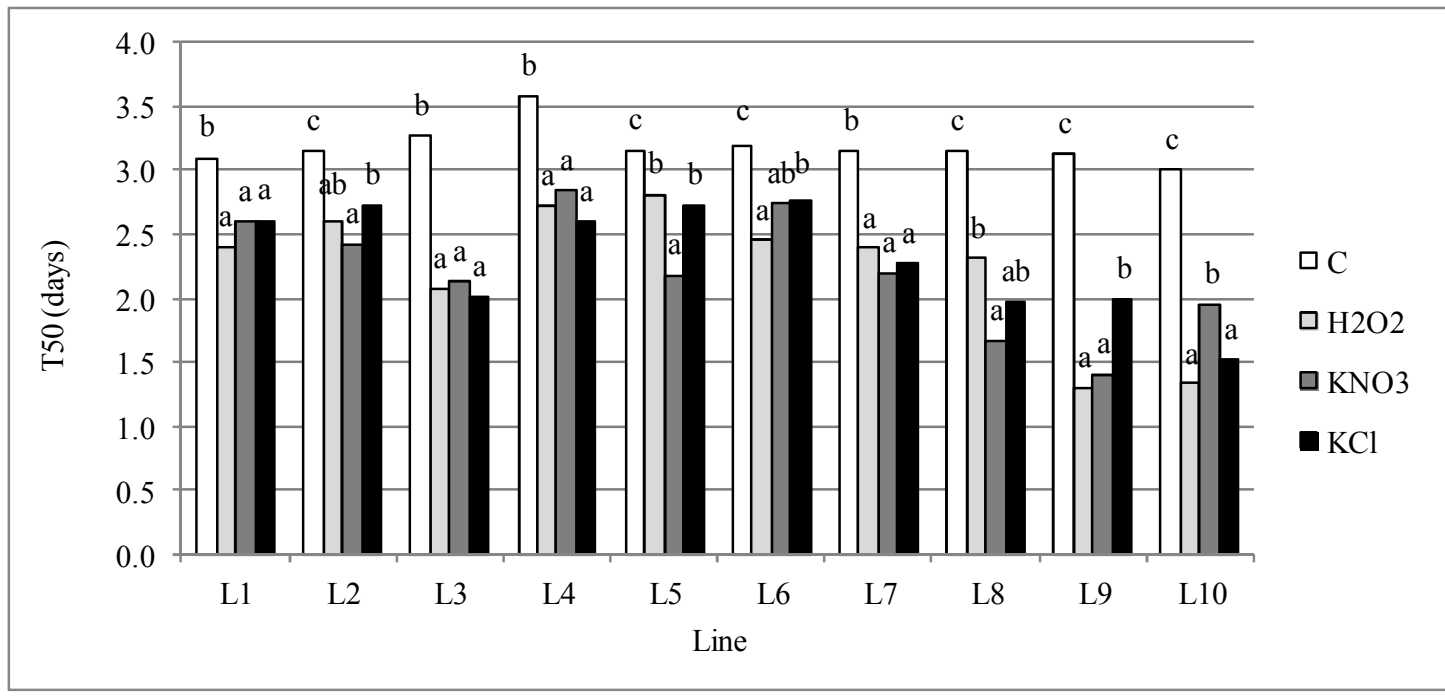

Germination was increased by $2 \%$ in $\mathrm{L} 1$ and by $1 \%$ in L2. At the starting value of $58 \%$, germination increased or decreased by $11 \%$. Quality increased with increasing starting values of germination, depending on line. Germination increased by $2 \%$ and $4 \%$ at $89 \%$. Therefore, priming with potassium nitrate was not dependent on the starting value of germination, but rather on soybean line, as also observed for the germination parameters MGT and T50. Although priming with potassium nitrate had the best results in terms of seed germination, it also had a lower effect on MGT compared to priming with potassium chloride and hydrogen peroxide. MGT ranged from 2.33 to 4.70. A positive response was observed in lines showing a significant increase in germination, including those in which no effect on seed germination occurred. T50 improved after treatment with this primer. Unlike MGT, this primer proved most effective in improving T50 values, which ranged from 1.41 to 2.84 . Priming with potassium nitrate has long been used for seed quality improvement in many plant species (McDonald, 2000). The use of this primer was effective for seed germination in soybean (Mohammadi, 2009), onion (Arin et al., 2011), bean (Umair et al., 2010), rapeseed (Mohammadi and Amiri, 2010), and gladiolus (Ramazan et al., 2010). This treatment had positive effects on seed vigor in rapeseed (Mohammadi and Amiri, 2010), seedling growth and germination index in low-germination sunflower (Singh and Rao 1993), dry matter content in seedlings, and seed vigor in soybean sown in late spring (Mohammadi, 2009). Nascimento et al. (2004) reported increases in the germination percentage and vigor of melon seeds under varied temperature regimes and subjected to potassium nitrate treatment. 
Miladinov et al. (2014) confirmed that the use of potassium nitrate in the crop sown in late spring has a positive effect on soybean seed germination. Rapid germination and root development improve survival chances as the result of better contact with deeper soil layers and better moisture absorption by these plants (Livingston and de Jong, 1990). The positive effect of potassium nitrate is attributed to the effect of higher nitrate levels (Benech-Arnold et al., 2000), better water and oxygen permeability (Baskin et al., 2000) and earlier nutrient mobilization (Bewley, 1997).

The potassium chloride solution had stronger effects, both positive and negative, compared to potassium nitrate. Germination increased by $11 \%$ or decreased by $1 \%$ at the starting germination values of $47 \%$ and $48 \%$. The increase in the starting value of germination by $10 \%$ resulted in a $12 \%$ increase and a $9 \%$ decrease in germination. Priming seeds exhibiting $79 \%$ and $89 \%$ germination did not reduce germination in lines L7 and L9, as it only affected the quality parameters MGT and T50. MGT values were improved in all lines, regardless of the effects of the treatment on seed germination and starting value of germination. The effects depended on soybean line. The average value of MGT was 3.39, ranging from 2.25-4.30, and 5.41-6.18 in the control. Treatment with potassium chloride had the lowest effect on T50, with the average values of 2.32 and 3.19 in unprimed seeds. Priming with potassium chloride does not depend on the starting values of seed germination but only on soybean line, as observed through the germination parameters MGT and T50. Potassium chloride is the most widespread source of available potassium (Fixen, 1993). It is used by grasses for the improvement of germination, sprouting and initial growth (Mista and Dwivedi, 1980). Priming onion seeds with potassium chloride solutions has better effects on seed germination as compared to control (Arin et al., 2011). This results from metabolic processes or osmotic adjustment (Bray et al., 1989). Priming seeds with potassium solutions improves potassium use efficiency in plants (Al-Mudaris and Jutzi, 1999). Potassium is important for certain enzymes (Taiz and Zeiger, 2006), as it increases their activity and neutralizes the negative effects of free radicals (Hu and Schmidhalte, 2005). This pre-sowing treatment led to an increase in germination by means of reduction in lipid peroxidation and improvement of antioxidant activity (Parmoon, 2013).

Hydrogen peroxide was the least effective in increasing the seed germination percentage in soybean. Positive effects were observed in four lines, in which germination increased by $1-10 \%$. No response and no change in germination were observed in lines L7 and L9. Priming with hydrogen peroxide had an inhibitory effect on the germination of four lines, as it reduced their values by $2-$ $10 \%$. Some lines responded positively to primers containing potassium salts, but hydrogen peroxide had negative or low effects on germination. Germination decreased in line L 5 by $4 \%$, while potassium salts improved seed germination by $4 \%$ and $12 \%$. Although seed quality was least affected by hydrogen peroxide, this treatment gave the highest value of MGT compared to the other treatments. 
The average value of this quality parameter was 3.21, which was 2.50 lower than in the control. When lines are observed individually, MGT values ranged between 2.00 and 4.45. Favorable effects were obtained for T50, which averaged 2.24 in the range of 1.30-2.81. In conclusion, potassium chloride used as a primer does not depend on the initial value of seed germination, but only on soybean line, as evidenced by the germination parameters MGT and T50. It was proved that the exogenous application of hydrogen peroxide can improve seed germination in dormant and non-dormant seeds (Bahin et al., 2011). In addition to an increase in seed germination, a positive effect was also observed for MGT and T50 in sunflower (Wahid et al., 2008). Moreover, the positive effect of this primer was observed under conditions unfavorable for germination. Wahid et al. (2007) determined that hydrogen peroxide increases germination and germination index in wheat grown on saline soils (Wahid et al., 2007). The use of hydrogen peroxide solution stimulates seed germination and vigor in wheat, due to increased peroxidase activity (Liheng et al., 2009). Hydrogen peroxide enhances seed quality in safflower, as it oxidizes germination inhibitors in the seed coat, thus improving germination (Dolatabadian et al., 2008).

\section{Conclusion}

Priming effects depend on line and treatment, whereas the starting germination values were not significant for the efficiency of this pre-sowing treatment.

A positive response to soaking was observed in some lines, while others exhibited an inhibitory response, with significantly reduced germination values.

All primers had a positive effect on the germination parameters MGT and T50. Lower values of these germination parameters were observed in lines which had a negative response to priming, compared to lines with improved germination, but they also had a more rapid radicle protrusion compared to the control.

In conclusion, there is no universal applicability of one single primer as it might trigger a negative response in some lines and cause reduced seed germination.

\section{Acknowledgments}

This research was supported by the Provincial Secretariat for Higher Education and Scientific Research, Vojvodina, Serbia, Project No. 142-4512509/2017-02 (2016-2019): „Sustainable production of plant proteins: soybean, microorganisms, response to climate changes". 


\section{References}

Ahmad R., Hussain S., Farooq M., Rehman A.U., Jabbar A. (2013): Improving the performance of direct seeded system of rice intensification by seed priming. International Journal of Agriculture and Biology, 15: 791-794.

Al-Mudaris M. A., Jutzi, S. C. (1999): The influence of fertilizer-based seed priming treatments on emergence and seedling growth of Sorghum bicolor and Pennisetum glaucum in pot trials under greenhouse conditions. Journal Agronomy and Crop Science, 182: 135-141.

Arin L., Polat S., Deveci M., Salk, A. (2011): Effects of different osmotic solutions on onion seed emergence. African Journal of Agricultural Research, 6: 986-991.

Bahin E., Bailly C., Sotta B., Kranner I., Corbineau F., Leymarie J. (2011): Crosstalk between reactive oxygen species and hormonal signalling pathway regulates grain dormancy in barley. Plant, Cell and Environment, 34: 980-993.

Baskin J. M., Baskin C.C., Xiaojie L. (2000): Taxonomy, anatomy and evolution of physical dormancy in seeds. Plant Species Biology, 15: 139-152.

Benech-Arnold R. L., Sanchez R. A., Forcella F., Kruk B. C., Ghersa C. M. (2000): Environmental control of dormancy in weed seed banks in soil. Field Crops Research, 67: 105-122.

Bewley J. D. (1997): Seed germination and dormancy. Plant Cell, 9:1055-1066.

Bray C. M., Davison P.A., Ashraf M., Taylor, R. M. (1989): Biochemical events during osmopriming of leek seed. Annals of Applied Biology, 102: 185-193.

Bray C. M. (1995): Biochemical process during the osmopriming of seeds. In: Kgel, J. \& Galili, G. (Ed.). Seed development and germination. New York: Marcel Dekker, 767-789.

Coolbear P., Francis A., Grierson D. (1984): The effect of low temperature pre-sowing

treatment under the germination performance and membrane integrity of artificially aged tomato seeds. Journal of Experimental Botany, 35: 1609-1617.

Dezfuli P. M., Sharif-Zadeh F., Janmohammadi M. (2008): Influence of priming techniques on seed germination behavior of maize inbred lines (Zea mays L.). ARPN Journal of Agricultural and Biological Science, 3: 22-25.

Dolatabadian A., Sanavy S. A. M. M., Chashmi N. A. (2008): The effects of foliar application of ascorbic acid (vitamin C) on antioxidant enzymes activities, lipid peroxidation and proline accumulation of canola (Brassica napus L.) under conditions of salt stress. Journal of Agronomy and Crop Science, 194: 206-213.

Dourado A. M., Roberts, E. H. (1984): Chromosome Aberrations Induced during Storage in Barley and Pea Seeds. Annals of Botany, 54: 767-779.

Ellis R. A., Roberts E. H. (1981): The quantification of ageing and survival in orthodox seeds. Seed Science and Technology, 9: 373-409.

Evenari M. (1984): Seed physiology: its history from antiquity to the beginning or the 20th century. Botanical Review, 50: 119-142.

Fixen P. E. (1993): Crop responses to chloride. Advances in Agronomy, 50, 107-150.

Harris D., Raghuwanshi B. S., Gangwar J. S., Singh S. C., Joshi K., Rashid A., Hollington, P. A. (2001): Evaluation by farmers of on-farm seed priming in wheat in India, Nepal and Pakistan. Experimental Agriculture, 37: 403-415.

Harris D. (2006): Development and testing of 'on-farm' seed priming. Advances in Agronomy, 90: 129-178. 
Hu Y., Schmidhalter U. (2005): Drought and salinity: a comparison of their effects on mineral nutrition of plants. Journal Plant Nutrition and Soil Science, 168: 541-549.

Hussain I., Ahmad R., Farooq M., Wahid A. (2014): Seed priming improves the performance of poor quality wheat seed. International Journal of Agriculture and Biology, 15: 1343-1348.

ISTA (2009): International Rules for Seed Testing. International Seed Testing Association. Switzerland.

Lekić S. (2003): Životna sposobnost semena. Društvo selekcionera i semenara Srbije. Beograd pp 303.9

Liheng H., Zhiqiang G., Runzhi L. (2009): Pretreatment of seed with $\mathrm{H}_{2} \mathrm{O}_{2}$ enhances drought tolerance of wheat (Triticum aestivum L.) seedlings. African Journal of Biotechnology, 8: 6151-6157.

Livingston N. J., de Jong E. (1990): Matric and osmotic potential effects on seedling emergence at different temperatures. Agronomy Journal, 82: 995-998.

McDonald M. B. (2000): Seed priming. Black M., Bewley, J. D. (eds), Seed technology and its biological basis. Sheffield Academic Press Ltd., Sheffield, UK. 287-325.

Miladinov Z., Balešević-Tubić S., Đorđević V., Đukić V., Ilić A., Čobanović L. (2014): Effect of soybean seed priming on germination and vigour depending on the seed lot and sowing date. Field and Vegetable Crops Research, 51: 110-115.

Miladinov Z., Balešević-Tubić S., Đorđević V., Đukić V., Ilić A., Čobanović L. (2015). Optimal time of soybean seed priming and primer effect under salt stress conditions. Journal of Agricultural Sciences, 60: 109-117.

Misra N. M., Dwivedi D. P. (1980): Effects of pre-sowing seed treatments on growth and dry-matter accumulation of high yielding wheat under rain-fed conditions. Indian Journal of Agronomy, 25: 230-234.

Mohammadi G. R. (2009): The effect of seed priming on plant traits of late-spring seeded soybean (Glycine max L.). American-Eurasian Journal of Agricultural \& Environmental Sciences, 5: 322-326.

Mohammadi G. R., Amiri F. (2010): The effect of priming on seed performance of canola (Brassica napus L.) under drought stress. American-Eurasian Journal of Agricultural \& Environmental Sciences, 9: 202-207.

Nascimento W. M., Cantliffe D. J., Huber D. J. (2004): Ethylene evolution and endo- $\beta$ mannanase activity during lettuce seed germination at high temperature. Scientia Agricola. 61: 156-163.

Ozdemir E., Sade B., Soylu S. (2012): Effects of seed priming on growth parameters and relative water content of bread wheat cultivars at drought and normal conditions. Journal of Selcuk University Agriculture and Food Sciences, 26: 25-30.

Parera A.C., Cantliffe D. J. (1994): Pre-sowing seed priming. Horticultural Reviews, 16: $109-148$.

Parmoon G., Ebadi A., Johanbakhsh S., Davari M. (2013): The effect of seed priming and accelerated aging on germination and physiochemical changes in milk thistle (Silybum marianum). Notulae Scientia Biologicae, 5: 204-211.

Ramazan A., Hafiz I., Ahmad T., Abbasi N. (2010): Effect of priming with potassiumnitrate and dehusking on seed germination of gladiolus. Pakistan Journal of Botany, 42: 247-258.

Schopfer P., Plachy C., Frahry G. (2001): Release of reactive oxygen intermediates (superoxide radicals, hydrogen peroxide and hydroxyl radicals) and peroxidase in 
germination radish seeds controlled by light, gibberellins and abscisic acid. Plant Physiology, 125: 1591-1602.

Singh B. G., Rao G. (1993): Effect of chemical soaking of sunflower (Helianthus annuus L.) seed on vigour index. Indian Journal of Agricultural Science, 63: 232-233.

Umair A., Ali S., Bashir K., Hussain S. (2010): Evaluation of different seed priming techniques in mung bean (Vigna radiate). Soil Environment, 29: 181-186.

Taiz L., Zeiger E. (2006): Plant physiology. $5^{\text {th }}$ ed. Sinauer Associates, Sunderland, MA .

Wahid A., Perveen M., Gelani S., Basra S. M. A. (2007): Pretreatment of seed with $\mathrm{H}_{2} \mathrm{O}_{2}$ improves salt tolerance of wheat seedlings by alleviation of oxidative damage and expression of stress proteins. Journal of Plant Physiology, 164: 283-294.

Wahid A., Noreen A., Basra S. M. A. Gelani S., Farooq M. (2008): Priming-induced metabolic changes in sunflower (Helianthus annuus) achenes improve germination and seedling growth. Botanical Studies, 49: 343-350.

Wattanakulpakin P. S., Photchanachai K., Ratanakhanokchai K. L., Kyu P., Ritthichai S., Miyagawa S. (2012): Hydropriming effects on carbohydrate metabolism, antioxidant enzyme activity and seed vigor of maize (Zea mays L.). African Journal of Biotechnology, 11: 3537-3547 


\title{
UTICAJ POTAPANJA SEMENA NA PARAMETRE KLIJANJA
} SOJE

\author{
Zlatica Miladinov ${ }^{1}$, Svetlana Balešević-Tubić ${ }^{1}$, Vojin Đukić ${ }^{1}$, Aleksandar \\ Ilić $^{1}$, Lazar Čobanović ${ }^{1}$, Gordana Dozet ${ }^{2}$, Larisa Merkulov-Popadić ${ }^{1}$ \\ ${ }^{1}$ Institute za ratarstvo i povrtarstvo \\ Maksima Gorkog 30, 21000 Novi Sad, Republika Srbija \\ ${ }^{2}$ Megatrend Univerzitet, Fakultet za biofarming \\ Maršala Tita 39, 24300 Bačka Topola, Republika Srbija
}

\section{Rezime}

Cilj ovog istraživanja bio je da se ispita efekat prajmera na parametre kvaliteta semena pri različitim početnim vrednostima klijavosti. Za istraživanje je korišćeno seme deset linija soje koje su selekcionisane na Institutu za ratarstvo i povrtarstvo u Novom Sadu. Početna vrednost klijavosti semena linija kretala se od $48 \%$ do $89 \%$. Seme je površinski sterilisano 3\% rastvorom natrijumhipohlorita, a onda je potapano u različite prajmere: kalijum-nitrat $1 \%$, kalijumhlorid $1 \%$, vodonik-peroksid $1 \%$ i kontrola - netretirano seme. Rezultati su pokazali da efekat prajmiranja zavisi od linije i tretmana, a da početna vrednost klijavosti semena ne utiče na efikasnost ove predsetvene mere. Neke linije su veoma dobro reagovale na potapanje, dok je kod drugih došlo do inhibitornog delovanja, pa se vrednost klijavosti značajno smanjila. Povećanje klijavosti se kretalo, u zavisnosti od linija i tretmana, do $12 \%$, a smanjenje do $11 \%$. Kod linija gde je primenom ove mere ostvaren pozitivan efekat, povećane su vrednosti i ostalih parametara klijanja: srednje vreme klijanja (MGT) i vreme do $50 \%$ klijavosti (T50). Linije koje su negativno reagovale na prajmiranje i kod kojih je klijavost smanjena imale su niže vrednosti MGT i T50, ali i bržu pojavu klicinog korenčića u odnosu na kontrolnu varijantu.

Dobijeni rezultati ukazuju na to da se ne može govoriti o univerzalnoj primeni jednog prajmera, jer se može dogoditi da on ne odgovara određenoj liniji, pa može doći do pogoršanja kvaliteta semena.

Ključne reči: klijavost, parametri klijanja, potapanje, seme soje 